\title{
More than naming of parts
}

\author{
Botany underpins the modern world, not only agriculture but medicine, material science, chemistry \\ and much more. Yet it has been belittled to the point where even the name botany is out of favour; too \\ outdated for a modern science. Thankfully botanical researchers continue to look forward, not back.
}

On the 11 July 1872 Nature published an open letter (Nature 6, 211-216) to the then Prime Minister, William Gladstone, complaining of the treatment of the Director of the Royal Botanic Gardens at Kew, Sir Joseph Hooker, at the hands of the First Commissioner of Works, Acton Smee Ayrton. It is a letter of barely described fury, signed by no lesser people than Charles Darwin, Charles Lyell, George Bentham, Thomas Henry Huxley and others. The letter praises both Hooker and his father William for their contributions to botany and their stewardship of Kew Gardens, and details a concerted campaign on the part of Ayrton to undermine Hooker and induce him to resign. This was a shot in a long battle in which the unquantifiable worth of Europe's foremost botanical garden was stacked against the too-easily calculated cost of maintaining it.

Such battles continue. Last year, Kew Gardens laid off 47 full-time scientists, in the face of budget cuts that saw funding from the Department for Food and Rural Affairs (Defra) reduced by over $£ 8$ million since 2010. Hardly the start that the newly appointed Director of Science, Kathy Willis was hoping for! But making a virtue out of adversity, at the end of February she unveiled a five year plan based around a mission to "document and understand global plant and fungal diversity and its uses, bringing authoritative expertise to bear on the critical challenges facing humanity today." This approach, firmly concentrating on the science that takes place at botanical gardens and the practical value of such investigations, would doubtless have been applauded by Darwin and his compatriots.

In this issue of Nature Plants, researchers associated with a number of botanical gardens in the USA present a similarly forward-looking view of their role in connecting an increasingly urban population with the agricultural systems that feed it (see Comment by A. J. Miller et al.). Executive Director of the United States Botanic Garden, Ari Novy, and his co-authors argue that botanical gardens, which have already proved effective in communicating the importance of conservation and biodivestity, are uniquely placed to inform on the related

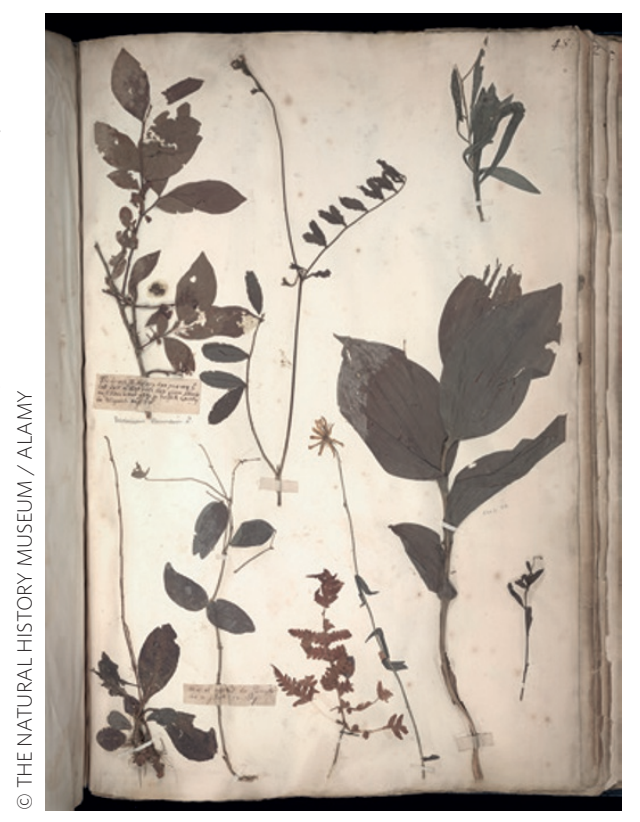

challenge of sustainability in agriculture. This again is not a new role; the first of all botanic gardens, the Orto Botanico, in Padua was established in 1545 as a collection of medicinal, and so utilitarian, plants.

Central to the work of all botanic gardens is systematic classification or classical botany. This has never been the most popular of disciplines. In a secret report commissioned by Ayrton during his fight with Hooker systematic botany was described as "attaching barbarous binomials to foreign weeds". Botany is no more fashionable now, with former botany departments changing their names to plant sciences or merging with zoology to form biology or biological sciences groupings. This could be regarded as simple semantics but there are dangers. For example in March a petition was started on the online lobbying site, change.org, to protest that the only plant biologist in University College London's Life Sciences division would not be replaced when they moved on later this year, effectively ending any plant component to undergraduate degrees there (http://go.nature.com/uq8IPj).

Perhaps botany has an image problem. Isabel Marques of the University of British Columbia and the University of Zaragoza, Spain argued in a recent Correspondence
(Nature 520, 295; 2015), that modern botany should be relying "less on pressed dead specimens and focusing on new molecular and systematic tools". But this might serve to draw attention away from the plants themselves "creating 'experts' who cannot reliably differentiate species" as Martin Kemler of the University of Pretoria, South Africa replied (Nature 521, 32; 2015).

Until DNA sequencers become handheld and solar powered there will be no substitute for classical botanical expertise when out in the field. Bradley Simpson, a pharmaceutical chemist at the University of South Australia who studies the properties of Australian plants used in traditional medicines believes that having a botanist as a collaborator in field projects is crucial. Without such expertise "I'd probably walk past [a significant plant] and not give it any notice" he says.

A small step to bringing botanical expertise into the hands of non-botanists is the free iPhone app, Plant-O-Matic (http://go.nature.com/9pg7vQ) developed by the Botanical Information and Ecology Network (BIEN). Gregory Goldsmith of the Environmental Change Institute, Oxford University, who helped develop the app says that the aim is to "re-envision what it means to be a field guide". The app gives access to the records of all plants in the Americas, over 88,000 species, systematically organized and linked to images of herbarium specimens from the Missouri Botanical Garden's Tropicos database. Crucially the app takes account of GPS location to filter results based on the known ranges of the plants. "It seems silly that as field researchers we still walk out with separate compass, GPS, field-guides and notebooks," says Goldsmith "this is fundamentally a way to take a piece of paper with a dead plant on it, stuffed in a drawer, and bring it back to life". Future developments of the app will include extending the range of plants beyond the Americas and allowing user observations to update the database.

Despite its central importance to life on earth, the study of botany has rarely been a headline-grabbing science. But the botanical community continues to focus its attention firmly on the future. 


\section{CORRECTION}

\section{More than naming of parts}

Nature Plants 1, 15086 (2015); published online 2 June 2015; corrected 4 June 2015

In the version of this Editorial originally published, the reference to the Comment should have cited A. J. Miller et al. This has been corrected. 